Aragón en la Edad Media

XXIV (2013)

pp. 293-326

ISSN 0213-2486

\title{
LA CASTELLANÍA DE AMPOSTA EN 1466-1468 A TRAVÉS DE SUS CAPÍTULOS PROVINCIALES
}

\author{
THE CASTELLANY OF AMPOSTA IN 1466-1468 \\ THROUGH ITS PROVINCIAL CHAPTERS
}

\begin{abstract}
Resumen: Este estudio se centra en los Capítulos que la Orden de San Juan de Jerusalén celebró en su "provincia" o delegación aragonesa, la Castellanía de Amposta, en 1466-68. Un órgano colegiado que reunía a la alta jerarquía del priorato, y, como garante del poder legislativo y reflejo a menor escala del Capítulo General de la Orden, administraba el señorío a través de sus decisiones y disposiciones. Al mismo tiempo, se comprobará cómo los registros de las actas capitulares reflejan de forma clara el convulso clima sociopolítico de la época y cómo esta circunstancia condicionó los intereses de la Orden Hospitalaria en la Corona de Aragón.
\end{abstract}

Palabras clave: Castellanía de Amposta, Orden de San Juan de Jerusalén, Capítulo Provincial, actas capitulares, Bernardo Hugo de Rocabertí.
JAVIER ORTIZ-ARZA

Universidad del País Vasco

\begin{abstract}
Summary: This article focuses on the Chapters the Order of Saint John of Jerusalem hold in its "province" or aragonese delegation, the Castellany of Amposta, in 1466-68, a collegiate institution that brought together thehigh hierarchy of the priorate, and, as a legislative power holder and a reflection at smaller scale of the Order's General Chapter, runned the lordship through its decisions and arrangements. The article will also demonstrate how the records of the Chapters minutes show clearly the eventful social and political climate, and how this conditioned the Hospitaller's interests in the Kingdom of Aragon.
\end{abstract}

Keywords: Castellany of Amposta, Order of Saint John of Jerusalem, Provincial Chapter, Chapter minutes, Bernardo Hugo de Rocaberti. 


\section{INTRODUCCIÓN Y OBJETIVOS}

Un códice diplomático conservado en el Archivo Histórico Nacional, en la sección Órdenes Militares y el fondo "Orden de San Juan de Jerusalén, Lengua de Aragón", es el núcleo principal de este estudio. El contenido de este manuscrito es doble, por un lado incluye las actas de diversos Capítulos que la Orden celebró entre 1466-1472 en su priorato aragonés conocido como Castellanía de Amposta, y, por otro, documentos emanados de estas reuniones que se consideró oportuno copiar, recopilar y conservar. Si bien por razones de espacio se ha limitado el análisis a las actas y la documentación del bienio 1466-68, tanto el mencionado volumen en toda su extensión como otros de similar contenido ofrecen un caudal de información de mucho interés para futuros estudios relacionados con esta Orden Militar y ámbito geográfico. En este caso, aprovechando el peculiar contexto histórico en que se enmarcan las fuentes analizadas, se ha pretendido realizar una aproximación a la realidad socioeconómica de la época desde la óptica de la propia Orden sanjuanista y con el extenso señorío de la Castellanía como escenario, con el objetivo de demostrar cómo la administración del territorio se vio absolutamente condicionada por un acontecimiento de primer orden que tuvo lugar durante estos años: la guerra civil catalana (1462-1472). Se comprobará, en definitiva, cómo los Hospitalarios de la Corona de Aragón atravesaron momentos de extrema dificultad en unos tiempos caracterizados por un clima de marcada conflictividad exterior que terminó por erosionar también el ámbito interno de la Orden. De forma paralela, se darán a conocer algunos aspectos relacionados con la administración de la Castellanía, y, en concreto, con el papel que desempeñaba el Capítulo en la misma, siendo algunas de sus funciones canalizar las relaciones con los vasallos o fijar tasas fiscales como las del relativamente desconocido tributo del capel. Por último, se definirán las características más formales de estas asambleas, desde el protocolo que implicaban, hasta el lugar de reunión, los asistentes o las cuestiones más relevantes que allí se debatían. Se incluirá, además, un breve apéndice documental como muestra de los documentos más significativos del registro analizado.

\section{LA CASTELLANÍA EN 1466-1468}

Si bien es necesario aludir a la importancia de aspectos como el insólito testamento de Alfonso I el Batallador o la disolución del Temple y posterior traspaso de sus propiedades al Hospital en el proceso de implantación de esta Orden en los dominios de la Corona de Aragón, no dejan de ser aconte- 
cimientos bien conocidos y documentados en lo fundamental, sobre los que, por tanto, no nos extenderemos más allá de su mención. Si nos trasladamos directamente a estas décadas finales de la Edad Media vemos ya a los sanjuanistas fuertemente arraigados en el territorio, y a la Castellanía de Amposta erigiéndose como uno de los señoríos más extensos y poblados del reino, con un centro de operaciones que ya no era el castillo de Amposta sino el palacio de la Zuda de Zaragoza, aledaño a una iglesia del siglo XII que había sido consagrada al patrón de la Orden, San Juan de los Panetes ${ }^{2}$. Este complejo era el lugar de residencia del castellán, escribanía y archivo — como demuestra la propia existencia de estos libros de gestión- y el lugar donde se reunía habitualmente el Capítulo Provincial, aunque las reuniones pudieran celebrarse de forma circunstancial en otros puntos de la Castellanía, como Caspe $^{3}$, la Almunia de doña Godina (1338 y 1351) o Gandesa, donde existía una camera capitularis reservada para esta función ${ }^{4}$.

Aunque las intitulaciones dobles que encontramos con frecuencia en la documentación sugieren que el Capítulo compartía la autoridad señorial con el castellán, limitando en cierta medida su poder personal, lo cierto es que este último era uno de los cargos con más prestigio y poder de la Corona de Aragón, pues, por ejemplo, asumía el mando de la milicia Hospitalaria en las campañas militares de la Corona y formaba parte de la Curia real. Los ingresos del castellán provenían de las cambras —encomiendas sin comendador reservadas exclusivamente para su enriquecimiento personal- $\mathrm{y}$ de las restantes comandas de las que sí era titular. El castellán Bernardo Hugo de Rocabertí (1415-1479), la persona que ocupó el cargo durante este período, recibía las rentas de las cuatro cambras de la Castellanía y de la encomienda de Monzón ${ }^{5}$. Los datos acerca de este personaje son escasos, pero sabemos que pertenecía a uno de los grandes linajes de la nobleza catalana de la época ${ }^{6}$ y es frecuente encontrar el apellido Rocabertí junto a los Sesé, Peralta, Heredia o Luna, entre otros, ocupando altos cargos en la jerarquía general de la Orden y también en la Castellanía. Los Rocabertí poseían un extenso patrimonio en la comarca

1.- María Bonet Donato, La Orden del Hospital en la Corona de Aragón: poder y gobierno en la Castellanía de Amposta (ss. XII-XV), Madrid, 1994, pp. 207-208.

2.- Así llamada por la costumbre que allí existía de repartir trigo entre los pobres, aspecto que aparece reflejado en AHN, Órdenes Militares, cód. L. 607, f. 96r.-97r., en relación a un litigio abierto entre el castellán y el comendador de La Almunia por la distribución de dicha limosna.

3.- Este fue el lugar de reunión del Capítulo de 1470 como así consta en la convocatoria a dicha reunión por parte del castellán en los folios 89r-89v de la misma fuente.

4.- M. Bonet, La Orden del Hospital, p. 267.

5.- AHN, Órdenes Militares, cód. L. 607, f. 16r.

6.- Sobre este particular existe un antiguo estudio, Josep DROMENDARI, Arbol genealógico de los viscondes de Rocabertí, condes de Peralta, 1676. 
del Ampurdán y formaban parte de una minoritaria aristocracia de sangre, los magnates o barones gerundenses, donde se incluían también otras familias preeminentes como los Cabrera, Cardona o Moncada ${ }^{7}$. Durante el siglo XV aparecen tomando parte en algunos episodios importantes. Por ejemplo, tanto Guillén como Guerau de Rocabertí, barones de Cabrenys y padre y abuelo de Bernardo Hugo respectivamente, participaron en la conquista aragonesa de Nápoles ${ }^{8}$, y el propio castellán junto a su hermano Pedro se implicó activamente en la guerra civil catalana como miembro del círculo íntimo de Juan $\mathrm{II}^{9}$. El futuro castellán aparece en 1449 en las actas de las Cortes como comendador de Alfambra de la Orden del Hospital y durante la guerra se dejó ver en algunos episodios militares junto a la causa realista, como la batalla de Calaf de 1465 o la campaña ampurdanesa del mismo año contra el condestable de Portugal, donde consiguió la victoria al mando de 2.500 hombres $^{10}$. Esta buena sintonía con la Corona explica, sin duda, que en junio de 1462 el propio rey se dirigiera al Convento de Rodas recomendando que el cargo de castellán, vacante en ese momento, fuera entregado a Rocabertí, que desde ese año aparece ya a la cabeza de la Castellanía ${ }^{11}$. En 1466 los embajadores enviados a Roma solicitaron una confirmación definitiva, destacando tanto los notables méritos de Bernardo Hugo en beneficio de la Orden como su probada ancianidad $^{12}$. Y es que, muy probablemente, su cargo era todavía provisional a la espera de ser confirmado por la autoridad pontificia, Pablo II, y por el maestre de Rodas. En los documentos emanados del Capítulo Provincial de 1466 aparece aún denominado como regente o comisario apostólico, —es decir, un delegado - pero en abril del siguiente año, quizás ya afianzado y sintiéndose legitimado por completo, exigió a sus comendadores el pago del llamado "derecho de capel", una tasa que como nuevo y legítimo castellán le correspondía cobrar. En septiembre de 1467 aumentó su patrimonio personal

7.- Santiago Sobrequés Vidal, "La alta nobleza del norte en la Guerra Civil Catalana de 1462-1472", en Cuadernos de Historia Jerónimo Zurita, nº16-18 (1963-65), p. 96.

8.- Narciso Feliú De la Peña y Farell, Anales de Cataluña, Barcelona, 1709, p. 331.

9.- AHN, Órdenes Militares, cód. L. 607, f. 16r. En 1468 las actas mencionan el fauor e calor que ha (el castellán) del señor rey.

10.- S. Sobrequés, op.cit, p. 152

11.- Enriq Bassegoda Pineda, "Vida i obra de fra Bernat Hug de Rocabertî", Gerona, Univ. de Gerona, 2012, p. 233.

12.- AHN, Órdenes Militares, cód. L607, f. 16r. En concreto se valora su capacidad para retener la Castellanía, que otrament ya fuera en otras manos fuera de la Religión de donde se havría havido razón de ninguna obediencia de la Religión, así como la virtud suya e amor e buen çelo que tiene a la Religión. Sobre ese concepto de ancianidad, que también se menciona en la fuente, sabemos que los Hospitalarios valoraban muy positivamente la veteranía de sus miembros a la hora de acceder a cargos de relevancia, algo que establecieron formalmente en 1478: Carlos BARQUERo GoÑI, "Las relaciones entre Rodas y los hospitalarios navarros durante el siglo XV", en Medievalismo. Revista de la Sociedad Española de Estudios Medievales, nº 5 (1995), p. 155. 
al serle concedida desde Rodas la encomienda llamada Las Carboneras ${ }^{13}$ y en mayo de 1478 figuró entre los asistentes a Cortes, aunque desapareció de ellas en 1479 por lo que probablemente falleció en algún momento entre las dos sesiones ${ }^{14}$. Las responsabilidades de Rocabertí al mando de la Castellanía y sus compromisos en la Corte no le impidieron cultivar su faceta literaria, que quedó plasmada en su obra poética "La glòria d'amor".

Rocabertí tuvo la mala fortuna de gobernar en una etapa muy conflictiva en el seno de la Castellanía y de evidente incertidumbre política en la Corona de Aragón, inmersa en un estado de guerra civil. No es de extrañar que el castellán buscara rodearse de un círculo reducido de personas que al parecer eran de su total confianza. Estos frailes acuden personalmente y con regularidad a las reuniones capitulares, ocupan cargos de relevancia y no aparecen vinculados, como otros muchos comendadores, a ninguna clase de controversia interna. Uno de ellos era el receptor fray Luis de Fluvián ${ }^{15}$, el encargado, entre otras cosas, de recaudar en cada encomienda las cantidades que la Castellanía debía aportar a la caja central de la Orden en Rodas, la llamada responsión. El cargo de receptor, al que se pueden referir los textos también como recebidor del Tesoro o tesorero, había aparecido en fecha tardía con el propósito de agilizar y asegurar la percepción de las numerosas contribuciones que la sede central de la Orden recibía desde sus prioratos ${ }^{16}$. Se podría pensar que este fraile estaba emparentado con Antoni de Fluvián y de la Riviere, maestre de la Orden entre 1421-1437, tal vez por el interés del Convento por tener a una persona cercana supervisando la valiosa tarea de recogida y desvío de rentas hacia Oriente, aunque Pierre Bonneaud afirma - sin referencia alguna que lo argumente- que era simplemente un miembro de la pequeña nobleza valenciana ${ }^{17}$. Sería en todo caso, según Bonneaud, una persona cercana al rey y al maestre, que le habría concedido personalmente la encomienda de Barbastro ${ }^{18}$. Fluvián perdió el apoyo de Rodas en 1468 cuando se le responsabilizó de haber abandonado su encomienda de Calata-

13.- E. BASSEGODA, op. cit., p. 234.

14.- S. SOBREQUÉS, op. cit., p. 155.

15.- AHN, Órdenes Militares, cód. L. 607, f. 2v. Fluvián es presentado como receptor e procurador general del Senyor nuestro e Conuento de Rodas, con plenissima potestat, segunt consta por bulla plúmbea que dada fue en Rodas durant el Capitol General.

16.- Carlos BARQuero GoÑI, La Orden de San Juan de Jerusalén en Navarra (siglos XIV y XV), Pamplona, Fundación Fuentes Dutor, 2004, p.109. La iniciativa deriva de un Capítulo General celebrado en 1358, donde se acordó que cada provincia contase con un receptor encargado de recaudar las rentas que hasta ese momento eran administradas por el propio prior, dándose en ocasiones un mal uso de ellas

17.- Pierre Bonneaud, Els Hospitalers catalans a la fi de l'edat mitjana. L'orde de l'Hospital a Catalunya i a la Mediterrània, 1396-1472, Lérida, Pagès, 2008, p. 302.

18.- En estas fechas el comendador de Barbastro era ya Juan de Alcañiz, mientras que Fluvián lo era de una encomienda más extensa: Calatayud. 
yud en manos enemigas en el contexto de la guerra civil, pero no así el de Rocabertí, que demostrando la confianza que le merecía este fraile respondió nombrándole su lugarteniente personal ${ }^{19}$.

Otros personajes cercanos al castellán y ocupados en tareas de relevancia eran los contadores, Gonzalo García, Pedro d'Orós y Domingo Cortés ${ }^{20}$, o los comendadores Juan y Luis de Azagra, seguramente parientes, y, en concreto este último, sustituto de Fluvián como receptor. Gonzalo de Ejea, comendador de Sarrión y Albentosa, realizaba habitualmente tareas de correo o informador, como sucedió en septiembre de 1466 cuando se le encargó elaborar un inventario de los bienes del fallecido Ferrari $\mathrm{Ram}^{21}$, o en los primeros días de 1468, cuando es enviado al reino de Francia en busca del prior de SaintGilles, representante del maestre ${ }^{22}$. Tampoco pasa desapercibido el aprecio personal que Rocabertí debía sentir hacia el escribano Juan de Peralta ${ }^{23}$. Así lo podemos comprobar en la doble suscripción notarial que aparece al inicio ${ }^{24}$, aunque resulta más que evidente que la de Peralta no fue la única mano que participó en su redacción. Esta tarea seguramente fuese compartida, entre otros, con Domingo Monient, nombrado notario general de la Castellanía de Amposta en diciembre de $1467^{25}$.

\section{El Capitol o Semblea Provincial}

El Capítulo Provincial de la Castellanía puede ser mencionado en las fuentes como Capítulo General, prueba, quizás, de una cierta tendencia a la autonomía de este priorato con respecto al poder central. Era, en todo caso, un órgano colegiado que venía a complementar o limitar el poder personal

19.- AHN, Órdenes Militares, cód. L. 607, f. 32v. E por evitar el debat de fray Fluviaá es stado fecho el dicho Fluviaá lugartenient del dicho castellán de Amposta.

20.- Ibídem, f. 3v. Cortés era prior mayor de Caspe y abad de Ontiñena.

21.- Ibídem, f. 7v.-8r.

22.- Ibídem, f. 32r.-33r.

23.- Ibídem, f. 86v. En noviembre de 1469 el castellán manifestaba tener en gran estima los servicios de Peralta, los quales son dignos de mayor retribución, y muestra su gratitud haciendo merced al notario de varias escribanías: la del justiciado de la villa y encomienda de Monzón, la de los tributos, comisos y actos del mismo lugar y castillo, la de los actos y negocios de la encomienda de Zaragoza, y la del justiciado, actos y negocios de la encomienda de Caspe.

24.- Ibídem, f. 1r. La suscripción consiste, como era práctica común en la Corona de Aragón, en la representación de sus signos acompañados de un texto. Podemos comprobar que se trataba de un notario público por nombramiento real y competencia general, serenísimo domini Regis Aragonum notarii publici per totam eius terram, al mismo tiempo que apostólico e imperial, auctoritatibus apostolica e imperialis notarius, algo lógico si tenemos en cuenta que estamos hablando de una Orden de marcado carácter internacional.

25.- Vid. doc. 9 . 
del castellán. La periodicidad de las reuniones era aproximadamente anual y servía para poner en común aquellas cuestiones que se considerasen relevantes para el buen gobierno y administración de la Castellanía, paso previo a su posterior plasmación documental. Era también la ocasión indicada para el vasallo que deseaba comparecer ante su autoridad señorial y solicitar una merced, y también para recibir a los aspirantes a ingresar en la Orden. No obstante, dos aspectos predominaban sobre el resto en las sesiones, por un lado los económicos, es decir, la gestión de la producción de las encomiendas y la administración fiscal de las mismas y por otro la elección de los embajadores que anualmente debían acudir al Capítulo General de la Orden - en estos años celebrado en Roma- para informar sobre la situación de la Castellanía.

El anuncio de reunión correspondía al castellán por medio de una carta abierta que fijaba la fecha de celebración del Capítulo y debía ser mostrada a cada uno de los invitados. Tal fue el proceso reflejado en un documento que circuló por el señorío durante los últimos días de 1467 convocando a los caballeros Hospitalarios de la Castellanía, que debían acusar recibo imponiendo su sello y rúbrica ${ }^{26}$. En 1466 el Capítulo arrancó el primer día de septiembre en Zaragoza y con el ritual, que, según se nos dice, era el rutinario: a son de campana segunt que otras veces la dita semblea, en la dita iglesia, por tales e semblantes actos es acostumbrado ${ }^{27}$. El lugar de reunión en esta ocasión, las casas nuestras de San Juan a las que se refiere el documento, fue sin duda el mencionado complejo que formaban el torreón de La Zuda y la iglesia de San Juan de los Panetes de Zaragoza.

Allí se congregaron el castellán, comendadores y otros altos cargos, como los priores y abades, o los notarios y escribanos encargados de redactar los libros de actas y las copias diplomáticas. Otro aspecto clave del ceremonial previo era la legitimación documental que facultaba a determinadas personas para tomas asiento en la Asamblea ${ }^{28}$, como era exigido, por ejemplo, a los procuradores de los comendadores ausentes. En caso de que algún convocado no pudiera o no considerase oportuno acudir podía ser representado por otra persona, que debía mostrar a los demás presentes el poder que le facultaba para ello. Así, en el Capítulo de 1466 fue Ferrando Ram quien actuó en nombre de Juan Ram, un acaudalado fraile titular de

26.- Vid. doc. 8.

27.- AHN, Órdenes Militares, cód. L. 607, f. 2v.

28.- Ibídem, f. 2v. Fray Luis de Fluvían, por ejemplo, fue presentado en el Capítulo de 1466 como receptor e procurador general del senyor nuestro e convento de Rodas, con pleníssima potestat segunt consta por bulla plúmbea que dada fue en Rodas durant el Capítol General. 
hasta tres encomiendas ${ }^{29}$, y Francisco de las Cuevas hizo lo propio por Pedro Fernández de Heredia, comendador de Cantavieja ${ }^{30}$. Era cosa corriente que las encomiendas se administrasen in absentia, o que el clima de guerra e inseguridad reinante en la Corona de Aragón durante estos años disuadiera a los convocados a Capítulo de aventurarse por los caminos. Fray Azbert de Villamarí, comendador de Mallén, se escudó en la meteorología y en razones de seguridad para no acudir a la Asamblea en enero de 1468, y, en una carta que fue leída ante los convocados, otorgaba poderes de representación a Juan Pallás: visto el mal tiempo de vientos e frío que se ha girado, e por no lexar aquella fortaleza visto el mundo cómo anda, he deliberado remeter todas las cosas al dito mosser Pallás, el qual tiene poder por mí de comparecer ante la dita asamblea e fazer qualquiere cosa que yo podiesse fazer $^{31}$. No obstante, como veremos en seguida, parece que los verdaderos motivos de Villamarí para ausentarse del Capítulo eran otros muy distintos. Las actas capitulares revelan que este fraile, también drapero de la Orden, un alto cargo del Convento, no contaba con la confianza de la Asamblea, que a finales de 1466 le había ordenado poner su encomienda bajo la obediencia del castellán ${ }^{32}$. Un caso de indisciplina tan manifiesto como habitual en estos años.

\section{GUERRA, USURPACIONES Y REBELDÍA}

La cronología propuesta para este estudio coincide con los años centrales de desarrollo de la guerra civil catalana (1462-1472), un conflicto bélico que afecto de manera directa a la Castellanía de Amposta y es sin duda la razón principal de los gravísimos problemas financieros y de control sobre sus propiedades que el señorío estaba padeciendo y que quedan perfectamente reflejados en las fuentes. Los datos sobre apropiaciones ilegítimas de dominios, destrucción y abandono de encomiendas, asedios, etcétera, son constantes en los textos, y la mayoría de asuntos tratados en los Capítulos de

29.- Ibídem, f. 3r. Era comendador legítimo de Ulldecona, Villel y Aliaga, y su apoderado le representaba en virtud de una carta pública de procuración que fecha fue en Ulldecona a onze días del mes de janero del anyo mil CCCC LX e dos.

30.- Ibídem, f. 3r. Segunt costa por carta pública de procuración que feyta fue en la ciudat de Nápoles a diez dias del mes de abril del anyo mil CCCC cinquanta e uno. Es posible que este Heredia sea el mismo que en 1488 ascendió al cargo de castellán.

31.- Ibídem, f. 29r.

32.- Ibídem, f. 15r. En concreto se le apremia a poner la encomienda de Mallén en poder del receptor de la castellanía d'Amposta o en poder de frayre de la Religión que sea segura la propiedad a la Religión, lo qual de presente no está. 
1466 y 1468 guardaban relación con esta circunstancia y con el avance de la guerra. No debemos olvidar que la Castellanía siempre fue una delegación o provincia de un poder central, lejano y desde luego ajeno a todo lo que estaba sucediendo en la Corona de Aragón. El maestre de Rodas demandaba regularmente el cobro de las cantidades que le correspondían, quizás sin ser del todo consciente de la complicadísima situación que sus hermanos aragoneses estaban padeciendo. La principal preocupación de Rocabertí durante este período fue intentar extraer de las pocas encomiendas que aún le guardaban lealtad el porcentaje de beneficios que debía dirigirse al Tesoro central, la ya mencionada responsio ${ }^{33}$, y recuperar el dominio sobre las que se habían perdido. Lo cierto es que muy pocos comendadores se encontraban en condiciones de cumplir con sus deberes, ya fuera por los estragos que la guerra había ocasionado en sus comandas, o por insubordinaciones que podían manifestarse de diferentes maneras. Por un lado vemos a miembros de la Orden con título legítimo de propiedad, que, por la circunstancia que fuera, bien por simple incapacidad o por estar abiertamente enfrentados al castellán y Juan II, se negaban a liquidar sus deudas. Otros, siendo también frailes Hospitalarios, carecían del título de propiedad que les facultaba para ocupar la encomienda. No faltaban los abandonos - son frecuentes los anuncios de dominios despoblados y derruidos-y las encomiendas ocupadas por personas completamente ajenas a la Orden y enemigas en ese momento de la Corona, como castellanos. El resultado final, en cualquiera de los casos, era que esas comandas escapaban al control fiscal de la Orden y no producían ya ningún beneficio.

La guerra civil originó serias fisuras en el seno de los Hospitalarios aragoneses. Hay menciones específicas a las devisiones e guerras en el Regno de Aragón e Principado de Catalunya y a los ocupadores e tirannos que asediaban y usurpaban las legítimas propiedades de la Orden ${ }^{34}$. La postura de Rocabertí de férreo apoyo al monarca no era ni mucho menos compartida por todos los frailes, y se encuentran abundantes datos que muestran a varios de ellos en conductas ambiguas o de desobediencia, cuando no de abierta rebelión. Quizás el caso más evidente en este sentido sea el de Juan Ram, que, sin renunciar a sus responsabilidades en la Orden — estaba, como hemos visto, presente en los Capítulos a través de su procurador- y siendo legítimo titular de varias encomiendas, no comulgaba con la política del castellán de apoyo a Juan II. En diciembre de 1466 sus encomiendas de Aliaga y Caste-

33.- Ibídem, f. 3v. Esta fue precisamente la cuestión que abrió la Asamblea de 1466, un recordatorio a los participantes de que no partissen de la dicha ciudat sin se fer la contenta al Tesoro o havenirse con el receptor de la dicha Castellanía.

34.- Ibídem, f.17r. 
llote se encontraban en situación de rebeldía, pues habían fecho la guerra al señor rey con los castellanos ${ }^{35}$, una circunstancia de la que el Capítulo culpó directamente a Ram condenándole a pagar los 22.000 sueldos que costaría restaurar y devolver ambas comandas a la obediencia de la Orden ${ }^{36}$. Al ya mencionado fray Azbert de Villamarí se le acusaba de un hecho similar, en este caso la ocupación de su castillo de Mallén por un tal Martín Vicent. Aunque el acusado se defendió argumentando que fue forzado a entregar la fortaleza ${ }^{37}$, sus explicaciones no convencieron a nadie, y la Asamblea concluyó en enero de 1468 que había renunciado a su encomienda al poner el castillo e vasallos de aquellas en personas laycas e fuera de la religión ${ }^{38}$. Todo parece indicar que las repetidas ausencias de Villamarí a las reuniones capitulares $^{39}$ colmaron también la paciencia de los asistentes, que determinaron enviar en su busca a Pedro d'Orós, un hombre del círculo cercano a Hugo de Rocabertí. En similar situación que los dos anteriores se encontraba el receptor del Tesoro, Luis de Fluvián, con la diferencia de que él sí contaba con la confianza del castellán. Su encomienda de Calatayud aparece ocupada por un intruso, en este caso un tal Nuño de Paradinas, castellano ${ }^{40}$, pero mientras desde Rodas se le culpaba personalmente de la situación, tanto el castellán como el Capítulo no dudaban de su buena fe, y así se lo trasladaron al maestre a través de los embajadores ${ }^{41}$. De poco sirvió. La cuestión que abrió la Asamblea de comienzos de 1468 fue precisamente la pugna entre Fluvián y el candidato a sustituirle en el cargo, Luis de Azagra, y tras lo que debió de ser un intenso debate en el que muxas parablas dixeron, el castellán optó por entregar la receptoría a Azagra, argumentando que faría lo que el señor maestre de Rhodas le mandava por sus bullas e letras ${ }^{42}$.

Otro caso manifiesto de morosidad y rebeldía fue el de Ramón de Siscar, comendador de Valencia y Horta, que adeudando importantes cantidades no se presentó en los Capítulos ni envió procurador ${ }^{43}$, procediéndose en con-

35.- Ibídem, f. 14r.

36.- Ibídem, f. 14r. Que el dicho fray Johan sea condempnado por el dicho Capitol General en dicha quantidat, como dichas propiedades no se puedan cobrar sino con la vetuperación e paga de los dichos XXII mil sueldos.

37.- Ibídem, f. 29r. Manifiesta que lo havía fecho por fuerca e cuentra su voluntat.

38.- Ibídem, f. $27 \mathrm{r}$.

39.- Vid. doc. 10.

40.- AHN, Órdenes Militares, cód. L. 607, f. 14r.

41.- Ibídem, f. 18r. Las órdenes concretas era manifestar cómo el comendador de Calatayud ha fecho toda su diligencia en la recuperación de su comanda con el señor Rey e por todos se faga instancia en la recuperación de aquellas e conservación de su officio en la receptoría.

42.- Ibídem, f. 27r.

43.- Ibídem, f. 6v. No es venido a la dicha semblea ni dado de sí razón alguna en fazer las dichas pagas en gran danyo del común Tesoro e cargo suyo. 
secuencia al embargo de sus bienes ${ }^{44}$. El comendador de Castiliscar Lope Díez de Escorón, por su parte, fue incluido entre los frailes conflictivos en el informe que los embajadores de la Castellanía trasladaron a Roma al cierre del Capítulo de $1466^{45}$, al igual que los ocupantes de las encomiendas de Azcón y Mirambel, protagonistas de una disputa que salpicaba al que fuera castellán y maestre hasta su muerte en 1467, Pedro Sacosta, que entregó estas comandas a su hermano y nieto a modo de fianza. Como cabía esperar ambos se negaban a abandonarlas si no se atendían sus reclamaciones, que en el caso de Galcerán Cirera en Mirambel eran nada menos que cient mil sueldos e promessa de rey de dar una comanda ${ }^{46}$. No hay que olvidar otra realidad frecuente en estos tiempos y bien plasmada en las actas, como era la de aquellos individuos, que, aun siendo miembros de la Orden, se adueñaban de encomiendas sin que estas les hubiesen sido concedidas ${ }^{47}$. Tal fue el caso de los frailes Miguel Ferriz y García de Rebolledo, que ocupaban las de Huesca y San Juan del Temple sin titol legítimo o Gonzalo de Sesé, que hacía lo propio en $\mathrm{Ambel}^{48}$. Horta, Castellot y Aliaga, por su parte, se encontraban en este momento abandonadas ${ }^{49}$.

De especial mención resulta la polémica surgida con el usurpador de Novillas, don Alfonso de Aragón fijo del señor rey, bastardo de Juan II, hermanastro de Fernando el Católico, antiguo maestre de la Orden de Calatrava y en estas fechas combatiente junto a su padre y Hugo de Rocabertí a favor de la causa realista en la guerra civil ${ }^{50}$. Era, pues, un aliado, pero en todo caso una persona ajena a la Orden y su presencia en una posición reservada a miembros genuinos era tolerada con reservas por el castellán, cuyas buenas relaciones con el monarca ${ }^{51}$ no le impedían en privado incluir el asunto de Novillas y don Alfonso entre los problemáticos ${ }^{52}$.

44.- Vid. doc. 3.

45.- AHN, Órdenes Militares, cód. L. 607, 15r.

46.- Ibídem, f. $15 \mathrm{r}$.

47.- María Bonet Donato, "Estructura gubernativa y fiscalidad en la Orden del Hospital en la Corona de Aragón bajomedieval", en La Orden Militar de San Juan en la Península Ibérica. Actas del Congreso Internacional celebrado en Alcazar de San Juan los días 23. 24 y 25 de octubre de 2000, p. 58. La autora responsabiliza de este fenómeno al modo de explotación rentista y absentista. La ausencia del titular de la encomienda favorecería, con más razón en una situación de colapso económico, que otras personas irrumpieran en ella y tomaran el control.

48.- AHN, Órdenes Militares, cód. L. 607, f. 15v.

49.- Ibídem, f. 14v. Horta se encontraba destruyda e los lugares de aquella desipados por causa de la guerra, un panorama similar al que existía en Castellot o Aliaga.

50.- Sophia Menache, "Una personificación del ideal caballeresco en el medievo tardío: don Alonso de Aragón”, en Anales de la Universidad de Alicante. Historia Medieval, Alicante, 1986, p. 17.

51.- AHN, Órdenes Militares, cód. L. 607, f. 16r. Se menciona el favor e calor que ha del sennor rey.

52.- Ibídem, f. 13v.-14r. Se utiliza el calificativo "ocupada", muy revelador, para definir el tipo de dominio que el infante ejercía sobre la encomienda. 
El estado de guerra e inseguridad era una constante en la Castellanía de los años 1466 y 1468, circunstancias que quedan de manifiesto en las fuentes cuando se refieren a la destrucción de los lugares e villas de la Castellanía d'Amposta, profanación e perdición de las comandas e comendadores de aquellas $^{53}$. El resultado, en cualquier caso, era siempre el mismo: la pérdida de dominio y control sobre la encomienda de donde ni responsión ni quales cargos de la religión no se pueden ni se esperan haver, de modo que muchas de las propiedades del Hospital en la Corona de Aragón no estaban en condiciones de procurar ningún tipo de renta. Los ingresos, en consecuencia, se desplomaron, y la Orden no podía cumplir con los pagos a Rodas ni tampoco asumir sus propias deudas internas. Este último aspecto quedó reflejado en sendas cartas remitidas el 28 de septiembre de 1466 al obispo de Tarragona y al patriarca de Alejandría, por un lado, y al concello de Tortosa, por otro, en relación a un censal que esa localidad adeudaba al Hospital. Tanta urgencia venía motivada por las presiones de los acreedores, y se identifica a uno en especial, un mercader valenciano de nombre Ferrux Beltrán ${ }^{54}$. Meses después la situación incluso empeoró, y se alude expresamente a las rebeliones como uno de los motivos de los impagos ${ }^{55}$.

A comienzos de 1468 la situación era de especial gravedad, con noticias de asedios en algunos puntos de la Castellanía. El 10 de febrero se redactó un mandato del castellán y los miembros del Capítulo a los vasallos e havitadores del señorío ordenando la reparación de las estructuras defensivas de los municipios: signifficamos vos que es muy necessario por el bien público de vosotros e por conservación de las fuertes, castillos, barvacanas e cavas en las comandas e lugares de nuestra Religión en la Castellanía d'Amposta por razón de la guerra que present es e por les devenidor, por lo qual los vasallos de la Religión, veniendo el caso, se han a recoger dentro las dichas fortalezas o barvacanas con sus bivres, bienes, ropas e personas, seyendo menester, segunt en nuestra Castellanía es costumbrado fazer ${ }^{56}$.

53.- Ibídem, f. $13 \mathrm{v}$.

54.- Ibídem, f. 10v.-11r.

55.- Ibídem, f. 32r. Por la perdición del priorado de Cathalunya todos los crehedores se son mudados en la Castellanía de Amposta y esto con consentimiento del prior de Portugal, por qual la dicha Castellanía sufre grandes congoxas como por causa de las rebelliones. Como consecuencia viene a muy pocos paguar los cargos del Tesoro.

56.- Vid. doc. 12. 


\section{LA ELECCIÓN DE EMBAJADORES Y EL PRIOR DE SAINT-GILLES}

Si algo se repetía cada año en las reuniones capitulares era sin duda la elección de los representantes de la Castellanía que acudirían al Capítulo General de la Orden, en estos años celebrado en Roma. La figura del embajador era tanto más importante en estos tiempos si tenemos en cuenta que era la manera más eficaz de informar al maestre sobre la gravísima situación que afrontaba el señorío y la razón de los constantes impagos, la guerra. Con el propósito de que los delegados trasladaran un reflejo lo más aproximado posible a la realidad se redactaban minuciosas instrucciones que contenían todo aquello que estas personas debían poner en conocimiento del maestre y la Asamblea General del Hospital. Durante el Capítulo de 1466 se nombró embajadores a los frailes Luis de Fluvián, Luis de Acosta y Buyl Ladrón, acordándose entregar 2.000 sueldos a cada uno de ellos para cubrir los gastos de los cuatro meses que duraría su viaje, cantidad que podía incrementarse si los compromisos de los viajeros requerían más tiempo ${ }^{57}$.

Los encargados de redactar las instrucciones, en noviembre de ese mismo año, fueron otros cuatro frailes nombrados a tal efecto, Gonzalo de Ejea, Alfonso de Marcilla, Juan de Azagra y Miguel Díez, y su contenido, si bien redunda en las cuestiones que se han venido mencionando, nos sirve para conocer qué medidas se tomaron para enfrentar la situación. Resulta incuestionable que el Capítulo se veía superado por las circunstancias, y solicitaba tanto al Papa Pablo II como al maestre libertades o poderes especiales que les permitiesen proteger los maltrechos dominios del Hospital en la Corona de Aragón. Se solicitó al pontífice una bula excomulgatoria para castigar a quienes ocuparan de forma ilegítima encomiendas o cualquier otra propiedad de la Orden ${ }^{58}$, y se reclamó la reforma de la regla a través de un nuevo estatuto que obligase a cada comendador a nombrar un lugarteniente encargado de administrar y vigilar la encomienda en ausencia del titular. El propósito era evidente: controlar el absentismo y evitar las usurpaciones de dominios ${ }^{59}$. Con la intención de agilizar la administración del señorío, el objetivo fue conseguir un permiso para unir, dividir y reformar encomiendas cuando se estimase necesario ${ }^{60}$, todo ello sin descartar la acción directa, ya

57.- AHN, Órdenes Militares, cód. L. 607, f. 4r.

58.- Ibídem, f. 15r. Se demandaba una bulla papal rigorosa contra todas e qualesquier personas que tienen occupadas rendas e propiedades de la dicha religión, sian escomulgados ipso facto y entredichas sus tierras, remota toda apelación.

59.- Ibídem, f. 15v. Se faga estatuto en el Capitol General que en cada un castillo e comanda de la religión haya de haver frayre de la religión que sea lugarteniente, absent el comendador, a elección del comendador de la lur comanda.

60.- Ibídem, f. $16 \mathrm{v}$. 
que se elevó una petición que implicaba la unión de armas contra usurpadores y rebeldes ${ }^{61}$.

Más de un año después, en enero de 1468, tan sólo uno de los deseos del Capítulo había cristalizado, la alianza militar. El día 26 del mismo mes se estableció que toda aquella persona que havra ocupado o daquí adelant ocupara castillos, villas, lugares e términos de aquellos vasallos, bienes, rendas, drechos e otras cosas pertenecientes a la dicha religión e Orden de Sant Johan disponía de diez días para replantearse sus acciones, de lo contrario se convocaría a los comendadores, priores y demás cargos de responsabilidad de la Castellanía para que en auxillio e favor al dicho senyor castellán contribuyeran a la recuperación de los bienes usurpados, aportando un número de hombres con sus buenos rozines e armas, que variaría según el caso. Así, el propio castellán colaboraría con vint hombres de cavallo mientras que las encomiendas con entre dos y tres dependiendo de su tamaño y potencial económico ${ }^{62}$.

La reacción de la alta jerarquía del Hospital a todos estos requerimientos fue, con toda seguridad, mucho menos contundente de lo esperado en Zaragoza. Consistió en programar una visita a la Castellanía del prior de San Gil, lugartenient del Capitol General, para comprobar la veracidad de lo manifestado por los embajadores ${ }^{63}$, una medida que implicaba necesariamente lentitud, sin contar con el considerable retraso del emisario. Los meses transcurrían y el prior no aparecía, ante la desazón del Capítulo, que, nuevamente reunido a comienzos de 1468 , se lamentaba de la demora ${ }^{64}$, acordaba enviar en su busca a Gonzalo de Ejea portando un nuevo informe, e insistía en augurar un horizonte cada vez más apocalíptico, refiriéndose en concreto a la total destrución de la Castellanía si no se tomaban medidas con celeridad ${ }^{65}$. Ramón Ricart, prior de Saint-Gilles, no llegó hasta Mayo de ese año, pero lo hizo con altísimas expectativas, pues fue presentado como visitador e reformador general de la Castellanía de Amposta, y de forma extraordinaria se convocó una nueva sesión capitular por orden del propio Ricart, que estaría presente en ella ${ }^{66}$. De carácter monotemático, las reuniones transcurrieron analizando la misiva enviada a la Corte por este representante maestral y la respuesta recibida. La relación de encomiendas ocupadas hecha por Ricart es de mucho interés - sirvan como muestra los ejemplos apuntados en páginas anteriores,

61.- Ibídem, f. 17r.

62.- Ibídem, f. 30v-31r-31v.

63.- Ibídem, f. 33v.

64.- Ibídem, f. 26v.

65.- Ibídem, f. 33r.

66.- Ibídem, f. 41r-43r. 
que se repiten - con especial mención al caso de Ulldecona, que se encontraba ahora en manos del maestre de la Orden de Montesa, y curiosamente el asiento aparece subrayado y más adelante señalado por una manícula ${ }^{67}$. La respuesta del rey en lo tocante a los rebeldes no resulta sorprendente. El monarca ordenó que los usurpadores sean punits e castigats y corran con todos los gastos derivados de la recuperación de les villes e castells de les tals desobedients ${ }^{68}$, como paso previo e indispensable antes de poner los dominios en poder de personas leales a la Orden. Respecto a la polémica en torno a su hijo y la encomienda de Novillas, no solo no se resolvió como hubiera sido del agrado del Hospital, sino que en su orden de restituir el priorato de Cataluña Juan II colma de beneficios a Alfonso. El 2 de Junio Hugo de Rocabertí anunció dicho restablecimiento con todas sus comendas e pertenencias sin empaxo alguno, e de pagar a don Alonso d'Aragón de las rentas, comandas e bienes de la Castellanía qualesquiera ynmiendas e recompensas que por la dicha causa se haya a fazer ${ }^{69}$.

Un rápido vistazo a la Castellanía dos años después nos muestra una situación más apacible. La guerra y los asedios continúan, y los asistentes al Capítulo de 1470 se lamentaban de los gastos que origina la defensa de sus castillos y bienes, aunque parece que los pagos se efectuaban ya con más regularidad. Se ordenó a los embajadores enviados a Roma mostrar los libros de cuentas al maestre, resaltando los buenos pagamientos que el dicho castellán e comendadores han fecho a pesar de los considerables gastos bélicos. En general, las instrucciones de este año contrastan con el pesimismo de épocas pasadas, pues nos informan de que el stado de la Castellanía por gracia de nuestro sennor Dios sta oy bien. Parece que la mayoría de encomiendas estaban ya ocupadas por personas leales a Hugo de Rocabertí y comenzaban a rentar, a excepción de una bien conocida, la comanda de Nouillas, la qual tiene don Alonso, fijo de sennor rey, la qual fray Foxá trebaja e por el castellán e comendadores le es fecha toda aquella ayuda e cara que fazer se puede, pero el adversario es tanto grande que no es de marauillar. Un caso, este de Novillas, llamado a enquistarse e incluso a empeorar, pues en estas fechas el rey otorgó también a su hijo la encomienda de La Almunia ${ }^{70}$.

67.- Ibídem, f. 45v.

68.- Ibídem, f. 44v.

69.- Ibídem, f. 47r.-48v.

70.- Ibídem, f. 101r.-101v. 


\section{LAS RELACIONES CON LOS VASALLOS}

Además del desarrollo de la guerra y sus efectos sobre el señorío, creemos que es necesario referirse a otro tipo de cuestiones que quedan bien reflejadas en estos papeles y no están exentas de interés. Exceptuando las menciones, ya indicadas, a la tradicional limosna de San Juan de los Panetes, es palmaria la ausencia de datos relativos a actividades caritativas, de evidencias que demuestren la existencia de algún complejo hospitalario, o, en definitiva, de algún indicio acerca de posibles labores que redundaran en beneficio de los vasallos a imagen de aquella organización austera y altruista concebida por el beato Gerardo en la Jerusalén cristiana. Sin que la falta de información signifique necesariamente que estos aspectos no estuvieran presentes en la Castellanía de mediados del siglo XV, los registros muestran a los Hospitalarios aragoneses de esta época como una autoridad señorial rentista e inmovilista, preocupada únicamente por extraer de las encomiendas los beneficios necesarios para engrosar la fortuna de sus notables miembros y las arcas del Tesoro de Rodas. Este hecho bien pudiera responder a una situación circunstancial — la complicadísima coyuntura económica no permitía por el momento centrarse en otras cuestiones-, o reflejar una tendencia progresiva por parte de los sanjuanistas aragoneses hacia el abandono de su esencia fundacional. Sí se encuentran referencias a actividades asistenciales, por ejemplo, en Rodas durante las mismas fechas, como la construcción en 1440 de un nuevo hospital ${ }^{71}$, o en otros lugares de señorío Hospitalario como Pisa, donde existía un sanatorio de 20 plazas atendido por un médico y un matrimonio que recibían únicamente 22 florines anuales para el mantenimiento del edificio ${ }^{72}$. Al margen de esta observación, el resto de relaciones que la Orden establecía con los vasallos y habitantes de la Castellanía pueden reducirse a dos: concesión de mercedes y nombramientos.

Como ya se ha indicado, el Capítulo era la ocasión propicia para muchos de presentarse ante la autoridad señorial y elevar sus súplicas. Así lo hizo un tal Pedro Puyol, mercader de Monzón, el primer día de septiembre de 1466, rogando al Capítulo la ratificación de un contrato del que no se aportan más datos. Se ordenó entonces reconocer el documento a Pedro d'Orós y Domingo Cortés, y, encontrándolo adecuado, se procedió a la confirmación de su contenido $^{73}$. Dos días después, los congregados en Zaragoza recibieron a Pedro

71.- AHN, Órdenes Militares, cód. L. 593, f. 157r. Es establit et hordenat l'hedificació de la enfermería nova per honor de Deu et espachament de la nova enfermería per repos dels senyors malauts.

72.- Anthony LutTrell, "The Hospitallers Medical Tradition: 1291-1530" en The Hospitaller State on Rhodes and it's Western Provinces, Norfolk, 1999, Capítulo X, p. 78.

73.- AHN, Órdenes Militares, cód. L. 607, f. 5r - 5v. 
Mañez, habitante de Mallén, quien, levantándolo a la vista del castellán, faze a vuestra reverenda señoría occular hostensión, mostró un escrito que le facultaba para plantar vid, con fadiga, loísmo e comiso ${ }^{74}$, en una parcela de nombre "El Majuelo Tierno", la cual habría cultivado y mantenido con anterioridad pagando regularmente el treudo ${ }^{75}$ acordado con el comendador, que eran setze sueldos dineros jaqueses en cada un anyo, y solicitaba le fuese confirmado ese derecho. El Capítulo resolvió que debía efectuarse una visita al terreno, visa occulariter dicta vinea, para corroborar que lo dicho por Mañez era cierto, como paso previo a atender su petición ${ }^{76}$.

Muy reverend senyor e honorable semblea. Devant vuestra senyoría comparece Miguel Sanz, scudero, hauitant en la ciudat de Huesca ${ }^{77}$. Así se presentaba ante el Capítulo el 28 de enero de 1468 este Miguel Sanz, pretendiendo que la Orden le concediera en treudo perpetuo una heredad llamada La Hortiella - perteneciente a la encomienda de San Juan de Huesca y recién recobrada del enemigo por el comendador Miguel Ferriz - a cambio de cincuenta sueldos anuales. La Asamblea accedió también en esta ocasión a los deseos del vasallo. En la misma situación se encontraba un lugar conocido como "Camposines", arrebatado a los rebeldes y reclamado por el concejo de La Fatarella para su explotación y puesta en cultivo ${ }^{78}$. El Capítulo solicitó a cambio de la merced un pago en especie consistente en nueve caffices de trigo meytadenco de ordio e de trigo ${ }^{79}$ mesura de Tortosa, que debían ser abonados anualmente cada 8 de septiembre, fiesta de la Natividad de María. El trato incluía el ademprio ${ }^{80}$, esto es, el ejido o tierras comunales, y excluía la juridición civil e criminal, fornos, molinos e dominicatura ${ }^{81}$.

74.- A través de la fadiga el señor se reservaba el derecho a autorizar las ventas y podía obtener el dominio útil a cambio de un $10 \%$ menos de lo acordado con el comprador o arrendador. El loísmo era la concesión de licencia para efectuar dichas ventas, por la que el señor recibía un $10 \%$ del valor de la transacción, y el comiso era el derecho a comisar o embargar la propiedad en caso de impago. José Manuel Latorre Ciria, «Los señoríos del arzobispo de Zaragoza en la Edad Moderna: Población y estructura de las rentas», en Estudios sobre el Aragón Foral, Zaragoza, 2009, pp. 72-73.

75.- Jerónimo Borao y Clemente, Diccionario de voces aragonesas, Zaragoza, Imprenta y Librería de D. Calisto Ariño, 1859, p. 249. Treudo: «pensión anual, de suyo irredimible, en reconocimiento de una cosa dada en tributación o enfiteusis». El treudo era sinónimo de la enfiteusis castellana y se caracterizaba por ser también permanente.

76.- Vid. doc. 1.

77.- Vid. doc. 11.

78.- Vid. doc. 6.

79.- José Yanguas y Miranda, Diccionario de antigüedades del Reino de Navarra, Pamplona, Imprenta de Javier Goyeneche, 1840, p. 314. Meitadenco: «voz que se usaba para significar las pechas que se pagaban en trigo o cebada, por mitad o mezclados». La cebada recibía el nombre de "ordio".

80.- J. BoraO, op. cit. p. 107.

81.- Eulalia Rodón Binué, Lenguaje técnico del feudalismo. Siglo XI en Cataluña, Barcelona, Instituto Antonio de Nebrija, 1957, p. 86. Dominicatura: «propiedad y dominio señorial». 
Existe también información relacionada con miembros de minorías religiosas. El 24 de septiembre de 1466 el castellán ordenó a Alfonso d'Ixar, notario de Monzón, que recibiese el juramento del judío Abraham Benfalu para hacerse cargo de la escribanía en la aljama de esa localidad por renuncia de Astruch Aborrabe, que es biexo e por su antigüidat no puede regir las notas e escrevanía que tiene en essa villa e aljama ${ }^{82}$.

El Capítulo podía recibir en primera instancia los votos de los candidatos a ingresar en la Orden, una formalidad que en estos tiempos adquiría una utilidad adicional debido a lo complicado que resultaba encontrar lealtades sólidas y asegurar la propiedad sobre las encomiendas y demás dominios. La Castellanía recibía periódicamente desde el Convento un número limitado de licencias para nombrar nuevos caballeros, sargentos o donados ${ }^{83}$, que recibían las tierras recuperadas de manos enemigas con la intención de ponerlas de inmediato bajo la obediencia y el control fiscal del señorío: la semblea aquesto quiere para comandarles las fortalezas de la Religión e no stén en poder de seculares ${ }^{84}$. Los aspirantes debían ser nobles y solteros, $\mathrm{y}$, aunque las urgencias bélicas podían motivar que las designaciones se hicieran in situ, generalmente el último trámite debía ser la ratificación maestral ${ }^{85}$. La regla y los estatutos expresaban a este respecto que qualquier fidalgo o ciudadano honrado que querrá poner su fijo en cavaller e frayre de la Religión de Sant Johan, primero lo deue presentar personalment en capitol o semblea de la Castellanía o priorado de do es natural ${ }^{86}$. Con esta premisa, el 28 de enero de 1468 el Capítulo consideró idóneo e sufficient al hijo de Juan Albión, noble y vecino de Zaragoza, qui son ciudadanos honorables e preeminentes de la dicha ciudat, y no encontró problema en aceptarlo como frayre cavallero de la Orden de San Juan ${ }^{87}$, sin embargo, tanto esta persona como otro candidato llamado Juan Farcén tuvieron que esperar al visto bueno definitivo del maestre, que llegaría a través de su lugarteniente, el prior de Saint-Gilles de Francia, al que el Capítulo solicita días después licencia de fer dos frayres, es a saber, Johan Farcén e Bertholmeu Albión, los quales son stados aceptados por la semblea ${ }^{88}$.

82.- Vid. doc. 4

83.- Anthony LutTrell, "The Structure of the Aragonese Hospital", en The Hospitaller State on Rhodes and its Western Provinces, Norfolk, 1999, Capítulo XIII, p. 322.

84.- AHN, Órdenes Militares, cód. L. 607, f. 33r.

85.- Ricardo Cierbide Martinena, Estatutos Antiguos de la Orden de San Juan de Jerusalén: versión original occitana y su traducción al español según el códice navarro del AHN (1314), Pamplona, Gobierno de Navarra, 1999, p. 28.

86.- AHN, Órdenes Militares, cód. L. 607, f. 28v.

87.- Ibídem, f. $28 \mathrm{v}$.

88.- Ibídem, f. 33r. 
Eran habituales los nombramientos de priores conventuales, una figura que estaba presente en cada encomienda y sin duda implicaba gran prestigio - no hay más que fijarse en las características de la documentación que acompañaba a estas investiduras-. El 4 de septiembre de 1466 se entregó el priorato de Samper de Calanda a Pedro Ros por renuncia del anterior titular, Juan de Tremps, expidiéndose un documento en lengua latina y validado mediante sello pendiente ${ }^{89}$. Esto nos indica que se utilizó el pergamino como soporte, un material que en estas fechas se reservaba ya para los documentos de especial relevancia. Estos priores debían estar, además, facultados para la cura de almas. Ros recibió esta capacidad de manos del arzobispo de Zaragoza, que a su vez actuó por orden de Rocabertí según un documento datado en Tudela el 13 de noviembre de este mismo año $0^{90}$.

Nos han llegado también noticias de una polémica a tres bandas que afectó a vasallos del señorío, Hugo de Rocabertí y Gastón IV de Foix, una Casa con la que el castellán ya había tenido algún roce en el pasado ${ }^{91}$. El 30 de septiembre de 1466 se redactó un mandamiento ordenando a Juan Sanz, García Lalanda, Pedro Lozano, Juan Bernat y García de Marta, vecinos de Castiliscar, que no pudieran llamarse ni actuar como caballeros por haber sido armados en Alfaro de forma irregular por el conde de Foix, cuando segunt la ley Despanya e fueros e costumbres del Regno de Aragón e hombre pachés o villano o de condición, senyor alguno, cavallero non pueda fazer ni armar si no solament el senyor rey o a quien él lo manda fazer por su comissión. Rocabertí recuerda a estas personas, que al parecer estaban causando algunos alborotos en la localidad, que no son caballeros ni sus hijos hidalgos y jamás lo serán, y les ordena personarse ante él en un plazo no superior a diez días desde el momento que recibieran la notificación ${ }^{92}$.

\section{EL DERECHO DE CAPEL}

Por último, es necesario referirse a la función del Capítulo como organismo fijador de las cantidades que se cargaban sobre las encomiendas a través de tributos como la ya mencionada responsión. En el registro estudiado se hizo traslado de un documento que aporta interesantes datos acerca de otro impuesto, en este caso poco conocido: la tasa del capel. Ya se ha visto

89.- Vid. doc. 2.

90.- AHN, Órdenes Militares, cód. L.607, 18r.-18v.

91.- S. SobReQUÉs, op. cit. p. 153. El autor menciona un episodio concreto en el que Rocabertí es hecho prisionero por conde y logra escapar.

92.- Vid. doc. 5. 
en páginas anteriores cómo Hugo de Rocabertí fue hasta 1466 un simple regente o delegado de la autoridad pontificia, y de qué forma los embajadores de la Castellanía llevaron instrucciones precisas de solicitar al maestre una ratificación definitiva que consolidase su liderazgo. Desde entonces, seguramente con esa confirmación ya en sus manos, comienza a intitularse como castellán y no como comisario apostólico. Pero el testimonio que confirma esta circunstancia es una escritura de abril de 1467 donde el castellán solicita formalmente a las encomiendas el pago del capel, un impuesto que el documento explica de la siguiente manera: quando por vacación de la Castellanía d'Amposta es proueydo en otra persona de castellán d'Amposta in Christo iure le pertenesce el drecho clamado del capel, según las antigas tachas de la Religión. Vemos que era, por tanto, un tributo de carácter personal que se venía recaudando desde tiempo atrás y que cada encomienda debía abonar al castellán cuando accedía al cargo. Es posible que el término "capel" aludiera al sombrero utilizado por el clero con el que, quizás, se escenificaba la "coronación" del nuevo castellán. El Capítulo fijaba las cantidades, que se cobraban de forma variable según el potencial de cada comanda, y han quedado reflejadas en el documento que se incluye en el apéndice. Estos datos nos sirven, además, para conocer la capacidad económica de las encomiendas, habida cuenta que las diferencias eran importantes. La bailía de Cantavieja, por ejemplo, debía pagar a Rocabertí 3.000 sueldos, mientras que la encomienda de Torrente de Cinca únicamente $100^{93}$.

\section{CONCLUSIONES}

Los registros capitulares de la Orden de San Juan en la Castellanía de Amposta que se conservan en el Archivo Histórico Nacional son una fuente histórica de especial interés, y constituyen un caudal de información que arroja luz sobre temas muy diversos. El volumen utilizado para este estudio se enmarca en un contexto cronológico muy determinado, el de la guerra civil catalana, y en sus páginas queda demostrado cómo la contienda afectó profundamente a la Castellanía. Todo parece indicar que la división política existente en la Corona de Aragón alcanzó también a algunos frailes del Hospital, que durante este bienio 1466-68 aparecen en situación de abierta rebeldía contra el castellán y su círculo íntimo, negándose a saldar sus deudas con la Orden y a presentarse ante la Asamblea, o llegando incluso a hacerles la guerra junto a los enemigos del rey Juan II. Son igualmente abundantes 
las menciones a la ocupación de encomiendas por parte de personas ajenas al Hospital, entre ellas el infante don Alfonso de Aragón, o por miembros legítimos que en actitud de desobediencia las ocupaban sin contar con la pertinente licencia. Muchas otras comandas se encontraban abandonadas o completamente arruinadas a causa de la guerra. Otras, sufrieron asedios, y hubo necesidad de reforzar sus estructuras defensivas. En líneas generales, se puede afirmar que durante el bienio 1466-68 la Orden había perdido el control de gran parte de sus propiedades en la Castellanía de Amposta. En consecuencia, las encomiendas ya no producían las rentas necesarias para la correcta administración del señorío, que no podía afrontar sus deudas internas ni tampoco cumplir con los pagos debidos al Convento de Rodas. La respuesta del maestre fue enviar a un delegado, Ramón Ricart, prior de SaintGilles, que verificaría la situación sobre el terreno y actuaría de mediador y representante maestral ante el rey Juan II. Se inició entonces un proceso de restablecimiento del orden, recuperación de dominios, entrega de los mismos a personas leales al castellán y castigo de rebeldes, que debieron cargar con los gastos que la empresa originó. Dos años después, en 1470, la situación había mejorado. Los pagos a Rodas se efectuaban con mayor regularidad, y varias encomiendas se encontraban ya bajo control del Hospital y produciendo beneficios, a excepción del enquistado y agravado caso de don Alfonso de Aragón y la encomienda de Novillas.

Se puede afirmar que existía una dualidad de poder entre el Capítulo Provincial y el castellán. Ambos, a un mismo nivel, representan la autoridad señorial, tienen sello propio con el que validan los documentos y toman en conjunto las decisiones que afectaban al devenir del señorío. Estas reuniones incluían a los comendadores, priores, abades y demás personajes de relevancia de la Castellanía de Amposta o sus legítimos apoderados, y de todos los debates como de la plasmación documental de los mismos se tomaba asiento en libros registro como el que nos ocupa. El principal cometido del Capítulo era la administración fiscal de sus dominios y la fijación de tasas como la responsión o el capel, sin olvidar la elección de los embajadores que en representación de la Castellanía acudían al Capítulo General de Roma. De manera accesoria, las reuniones capitulares servían para escuchar las súplicas de los vasallos, realizar nombramientos de cargos o recibir a nuevos caballeros. Pocos datos encontramos en las actas capitulares acerca de actividades caritativas u hospitalarias, aquellas que desde su fundación en la profunda Edad Media habían popularizado el nombre de la Orden de San Juan de Jerusalén a lo largo de la Cristiandad. En su lugar encontramos una oligarquía señorial rentista e inmovilista que parece haber abandonado la esencia fundacional de sus orígenes. 


\section{ApÉNDICE DOCUMENTAL}

1466, septiembre 3. Zaragoza.

Fray Bernardo Hugo de Rocabertí, comisario apostólico en la Castellanía de Amposta, y el Capítulo Provincial de dicho priorato ordenan una visita a la tierra llamada "El Majuelo Tierno", de la encomienda de Mallén, antes de confirmar el uso de la misma a Pedro Mañez tal y como éste les solicita en la súplica inserta.

AHN, Sec. Órdenes Militares, Códice L. 607, folio 9r-9v.

\section{Littera comissoria Petri Manyes}

Frater Bernardus Hugonis de Rocaberti, etcétera, et nos fratres Ludouicus de Fluuián, Calatayud, Petrus d'Exea de Sarrión e de Aluentosa, Buyl Ladrón de la Almunia, Johannes d' Açagra de Sant Johan d'Oscha, Alfonsus de Marcilla de Alfambra, Ludouicus d'Açagra Templi Osce, Petrus d'Orós de Torrent de Cinca, Micael Díez de Anyón, preceptores, Dominicus Cortés, prior maior conuentus ville de Casp, Raymundus Tudón, conuentualis conuentus ville de Casp et abbas de Calamera, Grauiel Barbarán, prior Sancti Iohannis ciuitatis Cesarauguste et de Ambel, et Petrus Ros, et Franciscus de Cueuas, procurator venerabilis fratris Petri Ferdinandi de Heredia, preceptoris de Cantauiella, Tristandus de la Porta, procurator fratris Iohannis d'Escaues, preceptoris de Xalamera, Paulus Tolsa, procurator fratris Galuani Tolsa preceptoris d'Enzinacorba, Iohannes Diez, procurator fratris Lupi Diez d'Ezcorón, comendator de Castelsiscar, et Gizpertus de Tolosa, procurator fratris Iohannis de Alcaniz, comendator de Barbastro, de la Horta, de Iunzano e de Sant Miguel de Fozes. Et deinde tota Asamblea dicti Ordinis et Castellanie, in ecclesia Sancti Iohannis domorum ciuitatis Cesarauguste conuocate et ad sonum campane congregati. Venerabile religioso nostro fratri Michael Díez, preceptori d'Anyon, et Iohanni Pallas, iureperito, procuratori venerabilis fratris Azberti de Villamari, preceptoris de Mallén, presentibus. Salutem et veram fiduciam in comisis.

In dita nuestra venerable Asamblea comparuit honorabilis Petrus Manyes, miles, hauitator ville de Mallén, qui quandam in escriptis obtulit suplicationis cedulam, tenoris seguentis:

Muy noble, reuerendos e magnífficos senyores. A vuestra reverenda señoría expone Pero Manyes, hauitant en la villa de Mallén, que como en días pasados el reuerendo e magníffico fray Azbert de Villamari, traper de Rodas e comendador de la comanda de Mallén del Orden de la santa casa del Ospital de Sant Iohan de Iherusalem, le haya dado a trehudo perpetuo con fadiga, loysmo e comiso e con otras diuersas condiciones en la carta de la tributación contenidas e especifficadas $/ /^{9 \mathrm{v}}$ la meytat de la tierra clamada el Malluelo Tierno de la dicha comanda, pora plantar hi vinya. En la qual mitat de tierra él haya plantado vinya e aquella tiene e poside de present podando e cauando aquella e teniendo e seruando las condiciones de la atributación e paguando el treudo, que es setze sueldos dineros jaqueses en cada un anyo el primero de janero o hun mes aprés al dicho comendador o a su legítimo procurador, segunt 
que de lo sobredito consta más largament por la carta de la atributación, de la qual faze a vuestra reverenda señoría occular hostensión. E agora por quanto dubda el dicho suplicant, que pues tiene la dicha vinya plantada e bien conreada, a causa de algunas maluadas personas le poria seyer tirada por el dicho comendador o por otro successor suyo en grant preiudicio suyo e de su drecho, por tanto suplica el dicho Pedro Manyes a vuestra reuerenda señoría quieran la dita atributación e todas e cada unas cosas en aquella contenidas lohar e aprobar, ratifficar e confirmar en tal manera, pues ha fecho las despesas en plantar la dicha vinya e conrear aquella, que el dicho suplicant e los suyos no puedan en tiempo alguno seyer espoliados de la dita vinya, paguando el dicho trehudo e seruando las condiciones de la dicha atributación. E haun que de iusticia e buena razón lo sobredicho se deua fazer encara el dicho suplicant lo haurá a vuestra reuerenda señoría a singular gracia e merce. Altissimus etcétera.

Qua quidem cedula modo prefixo oblata, ydem suplicans debite suplicauit ut contenta in dita suplicacione exsequeremur.

Et nos visa preinserta cedula ad plenum, confidentes de industria et vestrorum probitate omnia et singula in preinserta suplicacione contenta, vobis duximus comitenda et comittimus seriem per presentem, ita tamen quod vos personaliter accedatis ad dictam villam de Mallén et visa occulariter dicta vinea, clamada el Malluelo Tierno, et contractu estabilimenti eiusdem et contenta in eodem si uobis bene uisum fuerit ipsum contractum et contenta in eo iuxta eorum $/ /{ }^{10 \mathrm{r}}$ seriem confirmetis, laudetis et aprobetis vice et nomine nostrum et dicti nostri Hordinis, atribuentes vobis super predictis omnibus et singulis cum incidentibus, dependentibus et emergentibus ex eysdem omnes vices nostras serie cum presenti.

Datum in ecclesia domorum sancti Iohannis Iherusalemitani ciuitatis Cesarauguste, durante celebracione dicte generalis asemblee, III die mensis septembris, anno a Natiuitate Domini millesimo CCCC LXVI.

1466, septiembre, 4. Zaragoza.

Fray Bernardo Hugo de Rocabertí concede el priorato de Samper de Calanda a Pedro Ros por renuncia del anterior titular, Juan de Tremps.

AHN, Sec. Órdenes Militares, Códice L. 607, folios 10r-10v.

\section{Collatio fratris Petri Ros}

Frater ${ }^{94}$ Bernardus Hugonis, etcétera. Religiosso in Christo nobis karissimo fratri Petro Ros, dicte domus. Salutem in Domino.

Ad grata et accepta seruitia per vos nobis impensa et que de cetero prestari esperamus ob hoc prioratum sancti Petri de Calanda dicti Ordinis, de presenti vacante per puram resignationem in manibus nostris de eodem facta per fratrem Iohannem de Tremps, vltimum posesorem eiusdem. Ea propter, ad nostram collationem seu 
dispossitionem deuolutum cum omnibus suis iuribus et emolumentis per religionem nostram et eius nomine per preteritores predecessores vestros solitus haberi, percipi et leuari cum omnibus oneribus et seruiciis diuinis dicto prioratuy espectantibus per vos habendum, tenendum, regendum et administrandum quamdiu vixeritis in humanis benefaciendo et honeste viuendo, deuote presentium de consillio fratrum nobiscum asistentium tanquam bene merito et condigno conferimus et donamus et in eodem prouidemus et vos investimus quo circa vniuersis et singulis fratribus et preceptoribus dicte Castellanie presentibus et futuris signanter preceptor sancti Petri de Calanda $/ /{ }^{10 \mathrm{v}}$ sub virtute secunde odedientie et hominibus et vasalliis dicte Castellanie et dicti loci de Calanda sub debito fidelitatis homagii quo nobis et dicto nostro Ordini sunt astricti, dicimus et mandamus quatenus vos, dictum fratrem Petrum Ros, in posessionen pacificam dicti prioratus inducant et inductum manu teneant a moto ad inde quolibet illicito detentore.

Si quis sit quem ${ }^{95}$ nos per presentes, amobemus et decernimus firmiter admonendum habendo vos in possesionem dicti prioratus manu tenendo ubique respondeant et responderi faciant de vniuersis iuribus et emolumentis ecclesie ipsius, quoquomodo pertinentibus, prout hactenus prioribus predecessoribus vestris in dicto prioratu responderi est asuetum et debet, et nullum obstaculum aut impedimentum ponant aut presumant alia ratione seu causa.

In cuius rey testimonium presentes vobis feci et sigillo impedenti iussimus comuniri.

Datum in ciuitate Cesarauguste, IIII die mensis septembris, anno quo supra.

1466, septiembre, 8. Zaragoza.

Bernardo Hugo de Rocabertí, comisario apostólico en la Castellanía de Amposta, manda que sean embargados los bienes de fray Ramón de Siscar, comendador de Valencia, por no haber efectuado los pagos debidos al Tesoro de Rodas.

AHN, Sec. Órdenes Militares, Códice L. 607, folio 6v-7r.

Littera emparatum fructuum

Fray Bernat Huc de Rocaberti, etcétera. A los amados e fieles nuestros, los bayles, justicias, jurados, conçellos, alamines, aliamas e uniuersidades de las comandas e baylías nuestras de Azcón, de Mirabet, de Horta e de Torrent, de Valencia e a qualesquier lugares e mienbros e tributarios de aquellas e de qualquier dellas. Signifficamos vos cómo en la dicha nuestra general semblea hauemos oydos e pasados todos los contos que los comendadores e comandas de la Castellanía de Amposta son tonidos al nuestro común thesoro de Rodas, entre los quales se es trobado que el reuerendísimo senyor Maestro de Rodas, olim castellán de Amposta, por las comandas de Azcón, de Mirabet es tonido al dicho común tesoro de Rodas fins a la present jornada sixanta

95.- Sic. 
seys mil $\mathrm{CC}^{\text {os }}$ quaranta quatro sueldos e seys dineros. E el venerable fray Ramón de Síscar por la comanda de Valencia es tonido dar de arrerages fins a la present jornada XII mil XXXI sueldos; e por la comanda de Horta, XII mil DCCCLXXXXVII sueldos. Por la qual razón, maguer clamado, el dicho fray Síscar no es venido a la dicha semblea ni dado de sí razón alguna en fazer las dichas pagas en gran danyo del común Tesoro e cargo suyo. Por lo qual el procurador del maestre y el conuento y común Tesoro de Rodas deuidament nos ha requerido que huiéssemos por testados e emparados todos e qualesquier fruytos, rendas y dreytos que por qualquiere vía, forma y razón siades tonidos dar e pagar al dicho Orden e al dicho senyor maestre, olim castellán, ni al dicho fra Síscar por razón de las dichas comandas o tributarios como comendadores ni encara qualesquiere arrendadores suyos como primero se han los drechos e rendas que el dicho común Tesoro ha en las dichas comandas. $/ /^{7 r}$

E por tanto por la fieldat que a nos e al dicho nuestro Horden sodes tonidos e en pena de dos milia sueldos a los coffres del dicho común Tesoro aplicaderos, vos decimos y mandamos que qualesquiere fruytos, tributos, peytas, rendas, drechos e emolumentos que al dicho Orden e al dicho senyor maestro, olim castellán, e a comendador $<$ Síscar $>$, soys tonidos en qualquiere manera, que aquellos tengades en poder vuestro por testados, emparados, interdeziendo vos ius las ditas penas todo linage de alienación e transportación de aquellos aduertientes vos no fagáys el contrario si las penas sobredichas deseháys euitar.

Datum ut supra.

1466, septiembre, 24. Zaragoza.

Bernardo Hugo de Rocabertí manda a Alfonso d'Ixar, notario de Monzón, que reciba el juramento del judio Abraham Benfalu para hacerse cargo de la escribanía de la aljama de los judios de esa localidad por renuncia de Astruc Aborrabe, notario de dicha aljama.

AHN, Sec. Órdenes Militares, Códice L. 607, folios 11v-12r.

Fray Bernat Huc de Rocaberti etcétera. Al amado nuestro Alfonso d'Ixar, notario de la villa nuestra de Monzón. Salut e buen amor.

Por parte de Astruch Aborrabe, judío, nos hes seydo suplicado que actendido que es biexo e por su antigüidat no puede regir las notas e escreuanía que tiene en essa villa e aliama, que le placía de su voluntat las dichas notas encomendássemos a Abrham ${ }^{96}$ Benfalu, judío e vasallo nuestro de aquexa aliama nuestra de Monzón. E nos confiantes de vos la comissión de las dichas notas fazedera al dicho Abrám, a vos encomendamos assí e en tal manera que en presencia vuestra el dicho Abram jure, segunt su ley, de hauerse bien e lealment en la //12r comissión de las dichas notas e en el usso e exercicio de la dicha escriuanía e en todos los actos de aquella, dándole

96.- Sic. 
por tenor de la present plena facultat de testifficar e en forma pública redegir todos e qualesquiere actos que los judíos notarios en aquexa aliama han acostumbrado testifficar e fazer.

E en testimonio de lo qual mandamos fazer las presentes, silladas de nuestro sillo e signadas de nuestra mano.

Dada en la casa nuestra de Sant Johan de Caragossa, el XXIIII día del mes de setiembre del anyo sobredicho.

1466, septiembre, 30. Zaragoza.

El castellán de Amposta ordena a Juan Sanz, García Lalanda, Pedro Lozano, Juan Bernat y García de Marta, vecinos de Castiliscar, que no puedan llamarse ni actuar como caballeros por haber sido nombrados por el Conde de Foix sin autorización real.

AHN, Sec. Órdenes Militares, Códice L. 607, folios 12v-13r.

El castellán d'Amposta

Hombres ${ }^{97}$ buenos. Entendido hauemos no con poca displicencia que vos, Johan Sanz, García Lalanda, mayor Pero Loçano, Johan Bernat e García de Marta, vasallos e vezinos del lugar nuestro de Castelliscar, fictament e dolossa e en gran frau e enganyo e en preiudicio del señor Rey e nuestro e de la nuestra Religión, e en danyo grant del concello e lugar nuestro de Casteliscar, hauríades ydo a los términos de la villa de Alfaro e suplicado al conde de Fox que vos fiziesse caualleros. E ya sea que segunt la ley d'Espanya e fueros e costumbres del Regno de Aragón e hombre pachés o villano o de condición, senyor alguno, cauallero non pueda fazer ni armar si no solament el senyor Rey o a quien él lo manda fazer por su comissión e no otro alguno. Empero vosotros contra toda iusticia e razón, affirmado vos esseyer fechos caualleros por el conde de Fox, la qual cosa fablando con su honor, él ni otri sino que sea Rey fazer non podía nin puede, vos nombráys caualleros e vuestros fijos fidalgos. Lo qual no soys nin podéys esseyer e ius aquel color ponéys escándalo e bolicio en el dicho lugar, en grant lessión e danyo irreparable $/ /{ }^{13 r}$ de la cosa pública, del dicho lugar e de los habitantes en aquella e total destrucción e crebantamiento de los priuilegios, usos e costumbres del dicho lugar e en grant offensa e danyo nuestro e de nuestra Religión.

Por tanto vos decimos e mandamos que vos o alguno de vos non vos nombredes caualleros ni fidalgos ni personas priuilegiadas en el dito lugar ni usedes de la llamada cauallería ni perturbedes a los jurados, concello, vezinos e habitadores del dicho lugar en sus usos e priuilegios de penyorar e prohibir vos que como clamados caualleros non rompades ni escaliedes tierras algunas en los dichos términos de Casteliscar ni fagades otras cosas a vosotros prohibidas, ius las penas prohibidas e espressadas en

97.- En el margen izquierdo: Castelsiscar. 
las sentencias arbitrales dadas e promulgadas antiguament entre el concello e fidalgos del dicho lugar, o si razones algunas hauéys por las quales lo sobredicho fazer no deuades aquellas, vengades ad allegar a la ciudat de Caragossa personalment, deuant de nos, a las casas de Sant Iohan, do habitamos, dentro de diez días aprés que la present vos será presentada. En otra manera instant e ${ }^{98}$ procurador del dicho concello e en continuacio de vosotros, procediremos contra vosotros, vuestras personas e bienes, segunt que por fuero, iusticia e razón e segunt los estabilimientos de nuestra religión trobaremos esseyer fazedor.

Dada ut supra.

1467, enero, 18. Monzón.

El castellán de Amposta cede al concejo de La Fatarella el lugar de Camposines, que se encontraba despoblado, para su puesta en cultivo a cambio de nueve cafices de trigo anuales que se entregarán al castellán y al comendador de Azcón.

AHN, Sec. Órdenes Militares, Códice L. 607, folios 23r-24v.

Tributacio uniuersitatis loci de la Fatarella

Fray Bernat Huc de Rocabertí, etcétera. A los fieles e amados nuestros los bayle, jurados e hombres buenos del concello e uniuersidat nuestra de la Fatarella, de la comanda e baylía nuestra de Azcón. Salut e buen amor.

Attendientes e considerantes nos hauer comisado e preso a mano nuestra el término culto e inculto del lugar siquiere partida de Camposines, miembro de la dita nuestra baylía de Azcón, por la despopulación de aquel por causa de la guerra et a los que affruenta con términos de Mora de Azcón de Corberá e Saluatierra. E por quanto es bien de nuestra Religión e haument de aquella que el dito término no remanga inculto e algunos singulares del dito lugar de la Fatarella culturauan en el dito término//23v , hauemos deliberado, a suplicación vuestra, dar a trehudo perpetuo a vos e a la dita uniuersidat el dicho término, segunt que deliberadament a vos lo damos al dito trehudo perpetuo con fadiga, loísmo, comiso e con las condiciones inffrascritas.

Primerament, que la dita uniuersidat de la Fatarella concellalment en cada un anyo sea tonida perpetualment pagar a nos e a la comanda, comendador e baylía de Azcón nueue caffices de trigo meytadenco de ordio e de trigo, mesura de Tortosa, segunt es acostumbrado pagarse el dicho trehudo en tiempos pasados, pagaderos en cada un anyo el día e fiesta de Santa María de setiembre e assí en cada un anyo. La qual paga comencará del día de Santa María de setiembre primero ueniente en hun anyo e assí en cada un anyo perpetualment en semblant día e fiesta. E queremos que no pagando el dito término sea caydo en comiso. E vos damos el ademprio del dicho término cumplament excepto la juridición ciuil e criminal, fornos, molinos

98.- Tachado: dicho. 
e dominicatura de aquel, las quales en nos detenemos. E que non podades vender, alienar ni permutar el dicho término en persona alguna, eclesiástica nin seglar, dantes e otorgantes a vos plena facultat de culturar e escaliar el dicho término, según en tiempos pasados es acostumbrado.

Mandantes, por la presente, al regidor de Azcón e qualesquier otros que la present seruen e no contrauengan ante aquella seruen cumplidament.

Dada en el castillo nuestro de Monzón, el diziocheno dia del mes de janero, del anyo de la Natiuidat de nuestro Señor mil CCCC sixanta siete. //24r

1467, abril 22. Zaragoza.

Fray Bernardo Hugo de Rocabertí reclama a cada encomienda el pago del llamado «derecho del capel» que le corresponde por haber sido confirmado en el cargo de castellán.

AHN, Sec. Órdenes Militares, Códice L. 607, folios 22r-22v.

Littere comissorie pro recuperando porcionem capucii

Fray Bernat Huc de Rocaberti, etcétera. A los amados e fieles nuestros los justicias, bayles, jurados, concellos, uniuersidades e hombres buenos de las villas e lugares e comandas nuestras de la Castellanía d'Amposta, e a cada uno de vos a quien las presentes preuendrán e presentadas sean. Salut e buen amor.

Bien crehemos no ygnorades que quando por vacación de la Castellanía d'Amposta es proueydo en otra persona de castellán d'Amposta in Christo iure le pertenesce el drecho clamado del capel, según las antigas tachas de la Religión, e como nueuament sehamos proueydo por nuestro señor el Papa e por el Capitol General del dicho Orden último, en Roma celebrado, et ipso foro hayamos succeydo en el drecho del dicho capel. Por tenor de las presentes, intimantes vos lo sobredicho, vos rogamos, encargamos e mandamos quanto más estrechament podemos e por la fieldat que al dicho nuestro Orden soys tonidos que el dicho drecho de capel a nos, como dicho es, pertenescient según la tacha, la qual sellada e autenticada vos enviamos, sacada de los regestros de la Religión, que //22r , lo que a cada uno de vos toca paguedes planament e sens dilación alguna en manera que mas despessas ni congoxas no sintades, e será cosa que en su caso e lugar muy mucho vos lo agradeceremos. E por cobrar el dicho drecho de capel hauemos fecho nuestro general comissario, procurador e receptor a Gaspar Sanz, official e seruidor nuestro, al qual en virtud de las dichas penas vos mandamos que hayades por comissario, procurador e official nuestro, e le déys conseio fauor e ayuda en todas las cosas que por él requeridos seredes toda dilación cessant.

Dada en las casas nuestras de Sant Johan de Caragossa, a XXII del mes de abril del anyo susodicho.

Las tasas sobredichas, sacadas del patrón de la Castellanía por mí, Johan de Peralta, notario, e del dicho senyor castellán, secretario, e aquellas por su mandado son según se siguen: 
Primo, los lugares de la comanda de Sant Johan d'Osca, Item, la comanda de Torrent de Valencia, Item, la comanda d'Orta e lugares de aquella, Item, la baylia de Cantauiella toda entera, Item, la comanda de Monzón e lugares de aquella, Item, la comanda de Billell con Sarrión e Aluentosa, Item, la comanda de Enzinacorba, Item, la comanda de Mallén, Item, la comanda de Alfambra, Item, la comanda de Samper de Calanda, Item, la Bata e Junçano, Item, Xalamera, Beluer, Santalezma e Estix, Item, la comanda de Nouillas, Item, la comanda de Calatayud e Villaluenga, Item, la comanda d'Anyón, Item, la comanda <de Barbastro $>$, Item, la comanda de Ulldecona, Item, la comanda de la Almunia, Item, la comanda de Alberit, Item, la comanda d'Ambel, Item, la comanda de Castelsiscar, Item, la comanda de Mirambel, Item, la comanda de Torrent de Cinca, Item, la comanda de Caragossa, Item, la comanda de Casp, Item, la baylia d'Azcón, Item, la baylia de Mirabet, mil sueldos mil sueldos mil sueldos tres mil sueldos

CCC sueldos DCC sueldos mil sueldos mil sueldos setecientos sueldos cincientos sueldos cincientos sueldos DC sueldos cincientos sueldos cincientos sueldos/22v setecientos sueldos trecientos sueldos mil sueldos setecientos sueldos trecientos sueldos cincientos sueldos CCC sueldos CCC sueldos cient sueldos mil seyscientos sueldos mil sueldos dos mil sueldos dos mil sueldos 99

Fuerunt expedite $<$ tres $>$ alie similes littere et fuerunt comissari dompnus Johannes Darmyo, Johannes de Luna et Martinus d'Exea, ecétera, large.

1467, diciembre, 28. Gandesa.

El castellán Hugo de Rocabertí convoca a Capítulo a los miembros de la Orden en la Castellanía de Amposta.

99.- En el margen izquierdo: faltan en el registro la baylía de Castellot, 2000 sueldos, la baylía de Aliaga 1000 sueldos, la comanda del Temple de Guesca 800 sueldos. 
AHN, Sec. Órdenes Militares, Códice L. 607, folios 24r-24v.

Frai Bernat Huch de Rocaberti, de la Santa Casa del Espital de Sant Johan de Iherusalem, humil castellán d'Amposta. A los venerables e honestos religiosos nuestros todos, los comendadores e frayres, priores e abbades de la Castellanía d'Amposta, e o a sus regidores, procuradores e administradores, e a sus logarestenientes e a qualquiera dellos a los quales las presentes prouendrán. Salut en nuestro Senyor Ihesu Christo.

Instant e requerient el venerable e religioso nuestro fray Loys d'Açagra, comendador del Temple d'Osca, receptor en la dicha Castellanía por el senyor maestro, conuento e común tessoro de Rodas, por las urgentes necessidades de nuestra Religión e del dicho común Tesoro de Rodas, e por dar horden en las cosas e actos de la dicha nuestra Religión ${ }^{100}$, fechos en el Capitol General del dicho Orden, último en Roma celebrado, lo qual es de suma necessidat con los comendadores e frayres con nos asistentes, hauemos deliberado mediant la gracia diuinal conuocar, tener e celebrar Capitol General de la dicha Castellanía en las casas $/ /^{24 \mathrm{v}}$ de Sant Johan del Espital de la ciudat de Caragossa el vicéssimo quinto día del mes de janero primero vinient. Por aquesto, a vosotros e a cada uno de vos, decimos e mandamos firmement y estrecha en virtud de santa obediencia, que vosotros sehades personament con nos en la ciudat de Caragossa el dicho vinticinqueno día de janero e con vos traygades vuestras responsiones e los arrerages por vosotros deuidos al dicho común tesoro de Rodas e qualesquiere otras cosas que seades tonidos dar e paguar fins a la present jornada, e los albaranes que paguado hauedes de la semblea últimamente celebrada por el prior de Portugal en el monesterio de Santa Fe fasta hoy.

Otrosí, vos dezimos y mandamos que leyda que hauréys la present, hi pongades cada uno de vos su sillo y vos sotascribades de vuestra mano en senyal de recepción, y la entredes al portador de la present por tal que ignorancia de la presentación de aquella no sea allegada. E no fagáys el contrario, si las penas sobredichas desehades euitar.

Dada ut supra.

Ell castellán d'Amposta.

Vista por mí, fray Azbert de Villamarí, a III de janero

Vista a IIII de jenero por Martín Vicent, procurador del senyor don Alfonso de Aragón por la comanda de Nouillas.

Vista por mí, Ferrando de Frexano, vicario d'Alberit, a $\mathrm{V}^{\mathrm{o}}$ de janero y el dicho senyor comendador es contento de fazer todo lo en la dicha littera contenido.

Vista por mí, Anthón de la Torre, alcayde d'Ambel e procurador de fray Goncalo de Sesse, a $V^{\mathbf{o}}$ de janero.

Vista por mí, fray Grauiel de Barberán, prior de Santa María del Temple de la ciudat de Caragossa, día martes a X de janero anno VIII ${ }^{\circ}$. 
Vista por mí, Sabastián de García, alcayde de Anyón, a Vº de janero.

Vista por mí, frare Luys de Fluuiá, comanador de Calatayud e receptor de la Castellanía, a VIII días del mes de giner. Protestant que lo dit comanador fray d'Açagra non eser legitem receptor, etcétera.

Vista por mí, frare Boyl de Ladró, comendador de la Almunya, present a hobeyr lo contengut en la littera.

1467, diciembre, 31. Zaragoza.

El castellán de Amposta nombra notario general de la Castellanía a Domingo Monient.

AHN, Sec. Órdenes Militares, Códice L. 607, folio 25r.

Fray Bernat Huch de Rocabertí, de la santa casa del Spital de Iherusalen, humil castellán d'Amposta. Al amado nuestro Domingo Monient, natural del lugar nuestro de Chiprana, así como a ydóneo e suficient al officio de notario, confiantes de vuestra bondat e por el sagrament en poder nuestro prestado de bien e lealment vos hauer en el oficio de notaría, por aquesto en notario general $<$ en $>101$ toda la Castellanía nuestra d'Amposta, por las presentes vos creamos, constituímos et hordenamos así que por toda nuestra Castellanía podáys usar e recebir e testificar qualesquier scripturas et hotros instrumentos públicos e priuado e aquellos redigue en pública forma, segunt que hotros notarios de nuestra Castellanía han costumbrado e suelen fazer, por nuestra actoridat e decreto; e que en iudicio e fuera de judicio le sea atribuyda plena fe, poniendo en aquellos vuestra subscripción e la autoridat nuestra.

Mandantes, por las presentes, a qualesquier frayres súbditos nuestros e a qualesquieres vasallos nuestros, que a vos hayan e tengan por notario e den plena fe en vuestros actos.

Mandantes vos seyer feyta la present e sellada con nuestro siello pendient.

Dada en ${ }^{102}$ las casas nuestras de Sant Johan de Caragossa, die última del anno de mil CCCC LXVIII ${ }^{103}$.

1468, enero, 28. Zaragoza.

El castellán y la Asamblea Provincial convocan a fray Azbert de Villamarí por considerar que ha renunciado a su encomienda de Mallén al ponerla en manos de personas ajenas a la Orden.

101.- Tachado: $d e$.

102.- Tachado: Caragossa.

103.- La datación según la Natividad del Señor contempla el inicio del año el 25 de diciembre, de ahí que la fecha que figura originalmente en el documento sea 1468. 
AHN, Sec. Órdenes Militares, Códice L. 607, folio 27r.

Muy reuerendo mosser e caro hermano. Por algunos negocios concernientes grautment el bien de la Religión e honor vuestra, senyalladament por quanto aquí se es publicado vos hauríades renunciado vuestra encomienda de Mallén e puesto el castillo e vasallos de aquella en personas laycas e fuera de la religión, lo qual no podemos creher, es de suma necessidat que vos vengáys de la part daqua personalment vista la present. E assí vos lo rogamos e encargamos, e en caso que no fuesse en vuestra facultat o recussássedes venir, lo que no crehemos, nos será forcado prouehir e prouehiremos en lo sobredicho según trobaremos ser fazedor, vuestra absentia no obstant. E por esta causa vos enuiamos a fray Pedro d'Orós, comendador de Torrent de Cinca, informado plenariament de nuestra intención, e de la nuestra present semblea, al qual vos placia dar plena fe e indubia crehençia de todo lo que de part nuestra e de la dicha semblea vos esplicará, poniéndolo por obra como de vuestra virtud speramos.

De Caragossa, die et anno prefixis.

Al muy reuerendo mosser e caro hermano don fray Azbert de Villamari, comendador de Mallén e draper de Rhodas. El castellán, comendadores e frayres de la Castellanía d'Amposta en semblea aiustados a vuestra honor prestos.

1468, enero, 28. Zaragoza.

El castellán de Amposta y los miembros del Capítulo Provincial de la Castellanía, atendiendo a la súplica inserta, conceden a Miguel Sanz, escudero y habitante de Huesca, a cambio de cincuenta sueldos anuales, una heredad llamada La Ortilla que había estado hasta ese momento en manos del enemigo.

AHN, Sec. Órdenes Militares, Códice L. 607, folios 34r-34v.

\section{Confirmatio tributationis Michaelis Sanz}

Frater ${ }^{104}$ Bernardus Hugonis de Rocaberti, sacre domus Hospitalis Sancti Johannis Iherusalemi, humilis castellanus Emposte, et nos, fratres Ludouicus de Fluuián, Calataiubi et Villaluenga, Huyl Ladrón Almunie, Johannes d'Açagra Sancti Johannis Osce, Gondisaluus d'Exea Sarrionis et Aluentose, Raymundus Síscar Torrentis Valencie et Horte, Ludouicus Daçages Templi Osce et receptor in Castellania Emposte, Michael Ferriz Sancti Johannis Osce, Petrus d'Oros Torrentis, insigne preceptores, Dominicus Cortes, prior de Casp et abbas Ontinyene, Michael Durán, regiens prioratum Almunie, Raymundus Tudon abbas Calauere, Petrus Puyazuelo, prior curatus $^{105}$ de Casp, Johannes Giner, abbas Vallonaris, Bertholomeus de Luna, prior Sancti Johannis Montissoni, Petrus Caxal, prior Sancti Johannis Cesarauguste, Johannes Pallas, procurator fratris Azberti de Villamari, preceptoris de Mallén, Franciscus de Cueuas, procurator fratris Petri Ferdinandez de Heredia, preceptoris Canthauetule,

104.- En el margen izquierdo: la encomienda de Huesca. Sos.

105.- Tachado: ville. 
Michael Garzes de Marcilla, vicarius Alfambre, procurator fratris Alfonsi de Marcilla, preceptoris Alfambre, Paulus Tolsa, procurator fratris Galuani Tolsa, preceptoris Enzinacorbe, honeste Michaeli Sanz, scutiffero hauitatore ciuitatis Osce. Salutem in Domino.

Per parte vuestra coram nobis fuit oblata suplicacio tenoris sequentis:

Muy reuerend senyor e honorable semblea. Devant vuestra senyoria comparece Miguel Sanz, scudero, hauitant en la ciudat de Huesca, el qual, con toda reuerencia, suplicando espone e dize que entre otras tierras pertenescientes a la comanda de Sant Johan de la ciudat de Huesca hay una heredat clamada La Hortiella siquiere el hospital de La Hortiella, la qual faze de trehudo a la dicha comanda cinquanta sueldos. De luengos tiempos ha que aquellos que han detonido la dicha heredat no han paguado los dichos treudos, ni encara reconoscían la dicha heredat seyer de la dicha comanda ni a daquella trehudera contra la verdat. E las cosas así estando el reuerend don fray Miguel Ferriz, comendador de la dita comanda de Sant Johan ${ }^{106}$ de la dicha ciudat, ha cobrado la dicha heredat para la dicha comanda e por quanto aquella estaua totalment dirruyda e hauía menester mucha cura ha aquella, dado e otorgado al dicho suplicant con cargo del dicho trehudo de los ditos cinquanta sueldos, paguaderos en cada anyo durant la vida del dito suplicant. E por quanto dessea la dita dación seyer válida, suplica a las vuestras senyorías queraes configurar la dita dación o concessión de la dita heredat fecha al dito suplicant e otorgar a dársela de nueuo para él e para sus herederos con el dicho trehudo perpetuo de los cinquanta sueldos paguaderos en cada un anyo, por tal que el dito suplicant con mayor voluntat pueda entender en la mylloración de la dicha heredat, lo qual el dicho suplicant reputará a singular gracia e merced, etcétera.

Et nos visis contentis in dicta suplicatione et in presenti instrumento $/ /^{34 \mathrm{v}}$ de super inserto rationibus et causis in dictis instrumento et suplicatione contentis, predicta omnia et singula contenta iusta ipsius seriem et tenorem laudamus, confirmamus et aprobamus.

$\mathrm{Si}$ sic est et nostrum decretum et actoritatem eydem imponimus et pro eorum corroboracione sigillo nostro impendenti sigillari mandamus.

Dada ut supra, XXVIII januarii.

1468, febrero, 10. Zaragoza.

El castellán de Amposta y los miembros del Capítulo Provincial ordenan que sean restauradas las fortalezas y demás estructuras defensivas de los lugares de la Castellanía para que sus habitantes puedan resguardarse en ellas durante la guerra.

AHN, Sec. Órdenes Militares, Códice L. 607, folios 33v-34r.

Prouissio reparacionis fortalicis

106.- Tachado: en la dicha comanda de Sant Johan. 
Fray Bernat Huch de Rocaberti, de la Santa Casa del Spital de Sant Johan de Iherusalem, humil castellán d'Amposta, e nos los comendadores e frayres de la dicha Castellanía, en asamblea conuocados e congregados en las casas nuestras de Sant Johan de Caragossa, según es costumbrado. A los amados e fieles nuestros, todos los vasallos e hauitadores en las comandas e baylías nuestras e a qualesquiere otros de la Castellanía nuestra de Amposta. Salut e buen amor.

Signifficamos vos que es muy necessario por el bien público de vosotros e por conseruación de las fuertes, castillos, baruacanas e cauas en las comandas e lugares de nuestra Religión en la Castellanía d'Amposta por razón de la guerra que present es e por les deuenidor, por lo qual los vasallos de la Religión, veniendo el caso, se han a recoger dentro las dichas fortalezas o baruacanas con sus biures, bienes, ropas e personas, seyendo menester, segunt en nuestra Castellanía es costumbrado fazer.

Por tanto mandamos, hordenamos e declaramos en la present nuestra semblea que toda hora que qualquiere comendador querrá obrar, cobrir e reparar las murallas e torres foranas e las barbacanas e cauas necesarias, según a él parecerá en los castillos e fortalezas que terna que los vasallos e consexo de tal villa o lugar sean tonidos de dar $\mathrm{e}^{107}$ ayudar de todos los jornales necessarios para la dicha obra, es a saber:

Que de los dichos jornales se hayan de fazer e conrear la lenya e piedra para la calcina e <algenz> que mester será, e más traer tierra e lenya para fazer regola e tella que mester será, e más carrear e tirar con sus bestias e jornales toda la piedra, arena, calcina <e algenz>, agua e las otras cosas necessarias e manobra que mester hi serán pora la dicha obra.

E más, hordenamos e declaramos que qualquier comendador que tales obras e reparaciones fazer querrá, que sea tonido de paguar todos los maestros, assín para tapiar como aparedar de piedra, o en otra manera; e los maestros que farán la calçinia, $<$ algenz>, tella e regola, e assí mesmo haya de paguar la fusta, clauos e maestros que la obrarán por $/ /^{34 \mathrm{r}}$ forma e manera que sea conseruación de las dichas fortalezas e propiedades, e benifficio e seguridat de los bienes e vasallos de nuestra Religión, a los quales mandamos por la fidelidat que nos son tonidos, que por ninguna cosa ni razón no recusen fazer las cosas susodichas si las penas de infieldat e inobediencia desehan euitar.

Dada ut supra, etcétera. 